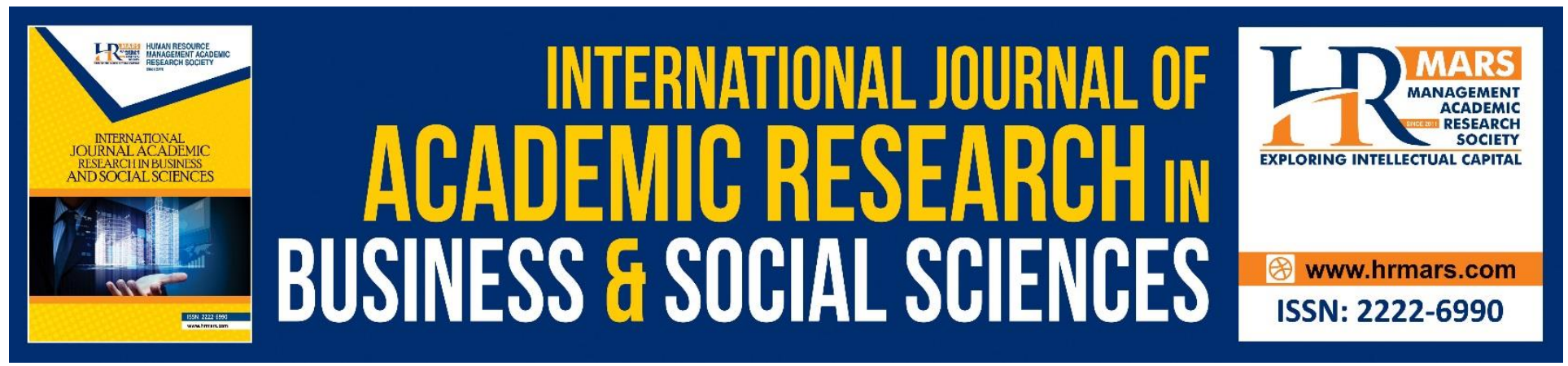

\title{
Social, Economic and Political Perspective of Social Media: A Case Study of Pakistan
}

\section{Zaeema Asrar Mohiuddin, Khalid Iraqi, Haider Iqbal}

To Link this Article: http://dx.doi.org/10.6007/IJARBSS/v8-i12/5321

DOI: $10.6007 /$ IJARBSS/v8-i12/5321

Received: 10 Nov 2018, Revised: 18 Dec 2018, Accepted: 26 Dec 2018

Published Online: 28 Dec 2018

In-Text Citation: (Mohiuddin, Iraqi, \& Iqbal, 2018)

To Cite this Article: Mohiuddin, Z. A., Iraqi, K., \& Iqbal, H. (2018). Social, Economic and Political Perspective of Social Media: A Case Study of Pakistan. International Journal of Academic Research in Business and Social Sciences, 8(12), 1760-1772.

\section{Copyright: (c) 2018 The Author(s)}

Published by Human Resource Management Academic Research Society (www.hrmars.com) This article is published under the Creative Commons Attribution (CC BY 4.0) license. Anyone may reproduce, distribute, translate and create derivative works of this article (for both commercial and non-commercial purposes), subject to full attribution to the original publication and authors. The full terms of this license may be seen at: $\underline{\text { http://creativecommons.org/licences/by/4.0/legalcode }}$

\section{Vol. 8, No. 12, 2018, Pg. 1760 - 1772}

Full Terms \& Conditions of access and use can be found at http://hrmars.com/index.php/pages/detail/publication-ethics 


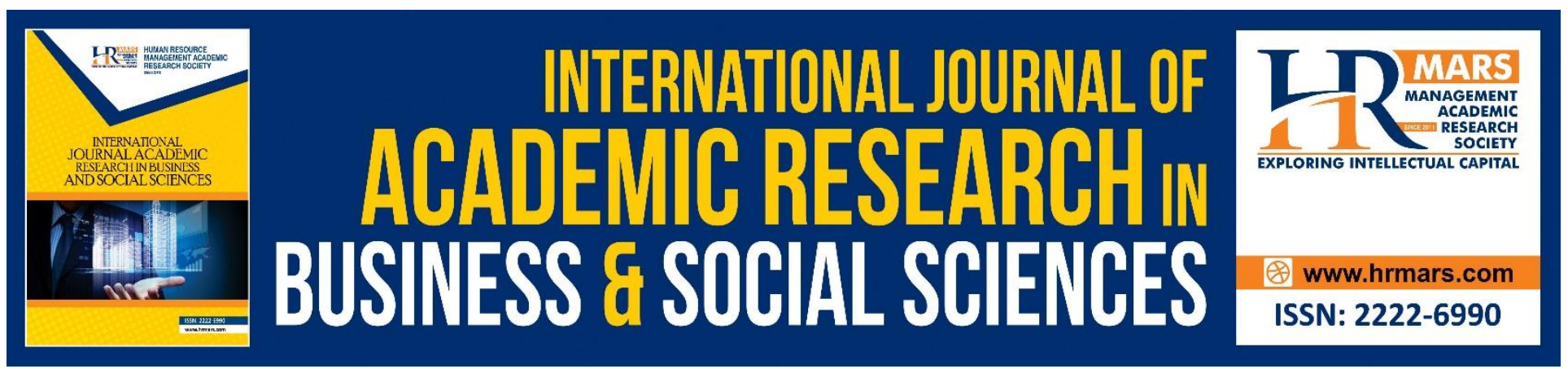

\title{
Social, Economic and Political Perspective of Social Media: A Case Study of Pakistan
}

\author{
Dr. Zaeema Asrar Mohiuddin \\ Assistant Professor, Department of Commerce, University of Karachi. \\ Dr. Khalid Iraqi \\ Professor, Department of Public Administration, University of Karachi. \\ Haider lqbal \\ Research Scholar, Department of Commerce, University of Karachi.
}

\begin{abstract}
The introduction of social media in Pakistan has greatly influenced the entire world. It has its footprints not only on social dimension but economic and political dimensions are also facing significant shifts due to the development of social media. The present study is aimed at highlighting the social media impact on social, economic and political facets in Pakistan. Relevant statistics and theoretical data are utilized to achieve the research objectives. This research is pioneer in its kind as it sums-up all the three dimensions i.e. social, economic and political of social media impact in the country. Results of the study reveal that social media in Pakistan is youth and male dominated. Facebook is the most commonly used social media site in Pakistan. It is the usage of social media which makes it either useful or damaging. Marketers have used several means to maintain the brand loyalty of their consumers; social media marketing is one of the modern means. Businesses employ social media experts to decide on content and features of their offers in social media sites. Social media, being youth intensive, is appealing political parties towards it. Pakistani politicians are progressively using social media to stay in close contact with their supporters and to gain the confidence of them.

Keywords: Social Media, Social, Economic, Political, Pakistan.
\end{abstract}

\section{Introduction}

Invention of internet is one of the greatest developments in the history of mankind. It is one of the bases which further strengthened the perception of global village. With the passage of time, effectiveness and efficiency of internet is rising. More and more opportunities, which help out the society, are being offered by internet, social media is counted among the most significant opportunity 
INTERNATIONAL JOURNAL OF ACADEMIC RESEARCH IN BUSINESS AND SOCIAL SCIENCES Vol. 8, No. 12, Dec, 2018, E-ISSN: 2222-6990 @ 2018 HRMARS

among them. Development of social media has brought a drastic change in various facets across the globe. Similarly, increasing usage of social media by Pakistanis is also altering the social, economic and political scenario of Pakistan. Several studies talk over the significance of social media for business success. Status of social media marketing is rising with the passage of time. For businesses, social media is simultaneously a source of customer voice and a method of direct marketing. Increasing usage of social media by politicians and involvement of their supporters and opponents on various activities can easily be seen. Political parties are utilizing social media platforms to win the confidence of people. Although, social media usage is getting popularity in various age groups however it is most popular among youth of Pakistan.

Table-1: Internet users in Pakistan w.r.t the total population - Date of estimation: Dec/ 2017

\begin{tabular}{|c|c|c|c|}
\hline Years & Internet users & Total population & Percentage of internet users in total population \\
\hline 2000 & 133,900 & $163,985,373$ & $0.082 \%$ \\
\hline 2006 & $12,000,000$ & $167,806,831$ & $7.151 \%$ \\
\hline 2009 & $18,500,000$ & $174,578,558$ & $10.597 \%$ \\
\hline 2010 & $18,500,000$ & $177,276,594$ & $10.436 \%$ \\
\hline 2016 & $34,342,400$ & $192,758,348$ & $17.816 \%$ \\
\hline 2018 & $44,608,065$ & $200,813,818$ & $22.214 \%$ \\
\hline
\end{tabular}

Source: Internet World Stats

Currently there are 44.608 million internet users in Pakistan which is $22.214 \%$ of the total population.

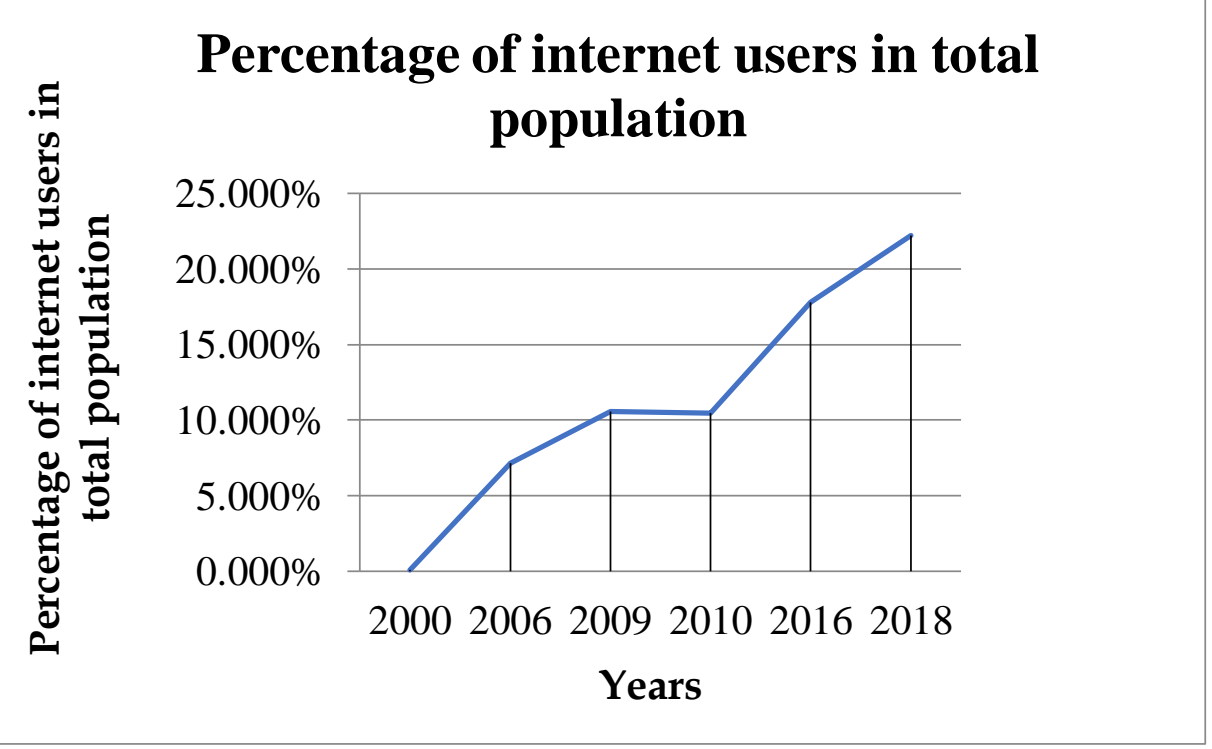

Graph is clearly showing that percentage of internet users in total population is increasing quite rapidly with the passage of time. 
INTERNATIONAL JOURNAL OF ACADEMIC RESEARCH IN BUSINESS AND SOCIAL SCIENCES Vol. 8, No. 12, Dec, 2018, E-ISSN: 2222-6990 @ 2018 HRMARS

Table-2: Percentage of social media users in the population which has access to internet in Pakistan - Date of estimation: April/ 2018

\begin{tabular}{|c|c|}
\hline $\begin{array}{c}\text { Social media } \\
\text { sites }\end{array}$ & $\begin{array}{c}\text { Percentage of social media users in population which has access to internet } \\
\text { in Pakistan }\end{array}$ \\
\hline Facebook & $92.06 \%$ \\
\hline Youtube & $04.68 \%$ \\
\hline Twitter & $01.50 \%$ \\
\hline Pinterest & $01.17 \%$ \\
\hline Instagram & $00.18 \%$ \\
\hline Google+ & $00.12 \%$ \\
\hline
\end{tabular}

Source: Aplha Pro - Pakistan's Digital \& Social Media Agency

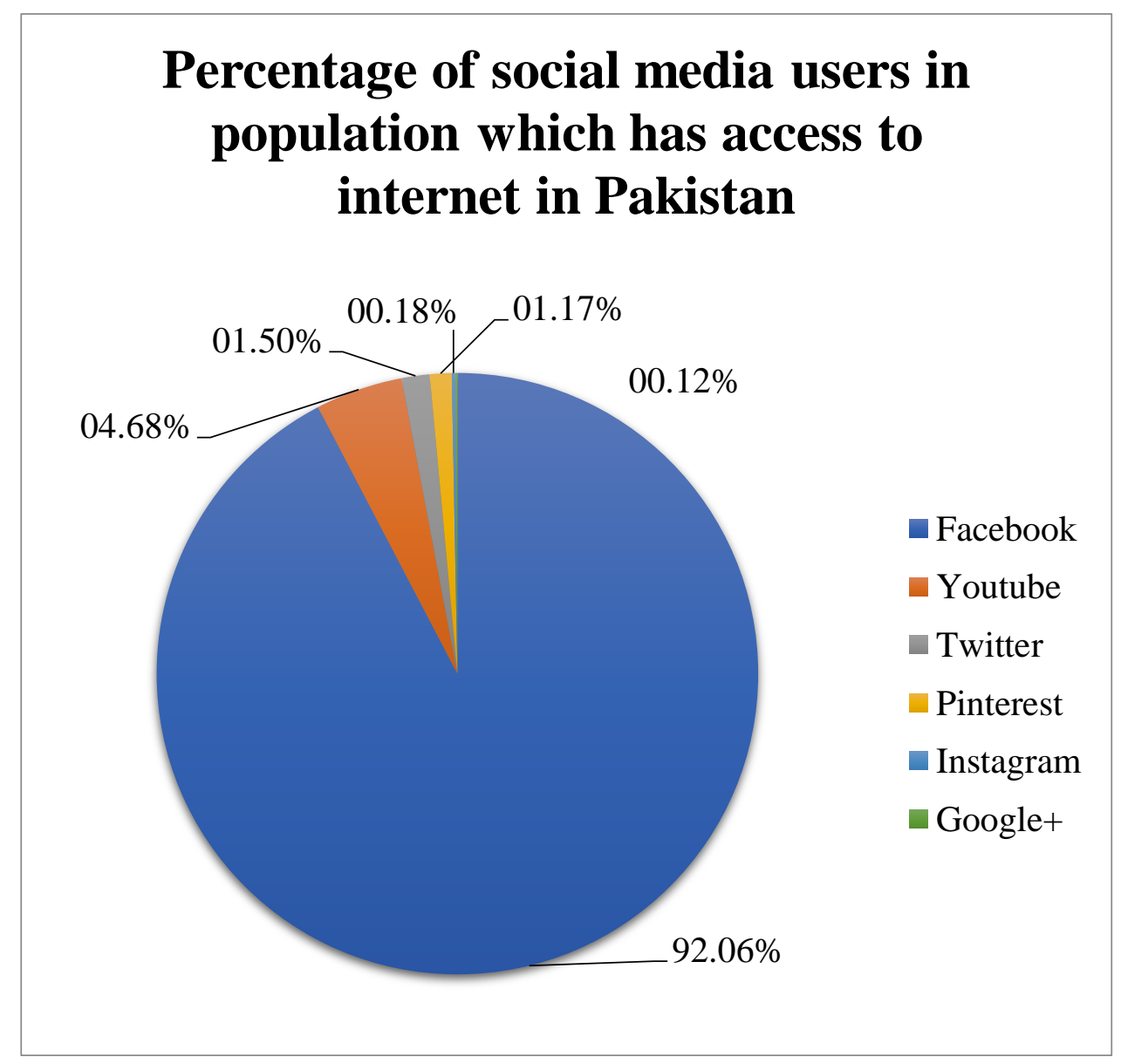

Facebook is clearly the most popular social media site in Pakistan with almost no comparison with other sites. It is used by $92.06 \%$ of the population which has access to internet in Pakistan. 
As social media has its footprints on almost all the spheres of life, the current study discusses the three major dimensions of social media influence i.e. social, economic and political in the scenario of Pakistan.

\section{Research Objectives}

1. To highlight the impact of social media on society of Pakistan.

2. To highlight the impact of social media on economy of Pakistan.

3. To highlight the impact of social media on politics of Pakistan.

\section{Originality}

The present study is unique in its kind as it portrays the overall image of social media impact by summing-up all the three spheres i.e. social, economic and political of social media impression on Pakistan.

\section{Literature Review}

Social Perspective of Social Media in Pakistan

Table-3: Genders Proportion of Facebook Users in Pakistan (million) - Date of Estimation:

\begin{tabular}{|c|c|c|c|c|}
\hline $\begin{array}{c}\text { Total Facebook } \\
\text { Users in million }\end{array}$ & $\begin{array}{c}\text { Total Male } \\
\text { Users in } \\
\text { million }\end{array}$ & $\begin{array}{c}\text { Total Female } \\
\text { Users in } \\
\text { million }\end{array}$ & $\begin{array}{c}\text { Percentage of Male } \\
\text { Users }\end{array}$ & $\begin{array}{c}\text { Percentage of } \\
\text { Female Users }\end{array}$ \\
\hline 35 & 26.95 & 8.05 & $77 \%$ & $23 \%$ \\
\hline
\end{tabular}

Source: Alpha Pro

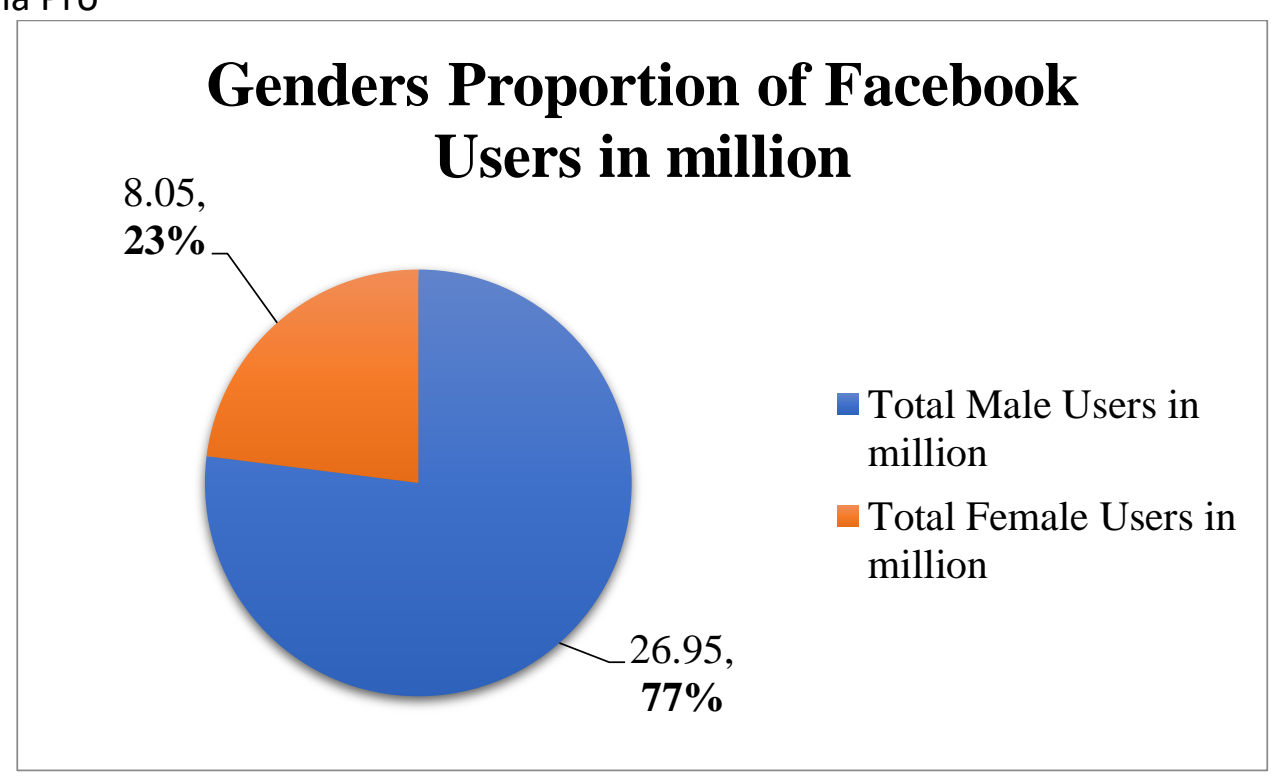

It is clear from the graph that majority of Facebook users are males. 
INTERNATIONAL JOURNAL OF ACADEMIC RESEARCH IN BUSINESS AND SOCIAL SCIENCES

Vol. 8, No. 12, Dec, 2018, E-ISSN: 2222-6990 @ 2018 HRMARS

Table-2: Tendency of Facebook usage in different age groups in Pakistan - Date of Estimation: End of January 2018

\begin{tabular}{|c|c|c|}
\hline Age Group & Facebook Users in million & Percentage of Facebook Users \\
\hline $13-17$ & 4 & $11.43 \%$ \\
\hline $18-24$ & 16.41 & $46.89 \%$ \\
\hline $25-34$ & 11 & $31.43 \%$ \\
\hline $35-44$ & 3.3 & $9.43 \%$ \\
\hline 65 and above & 0.29 & $0.83 \%$ \\
\hline
\end{tabular}

Source: Profit by Pakistan Today

\section{Facebook Users in million}

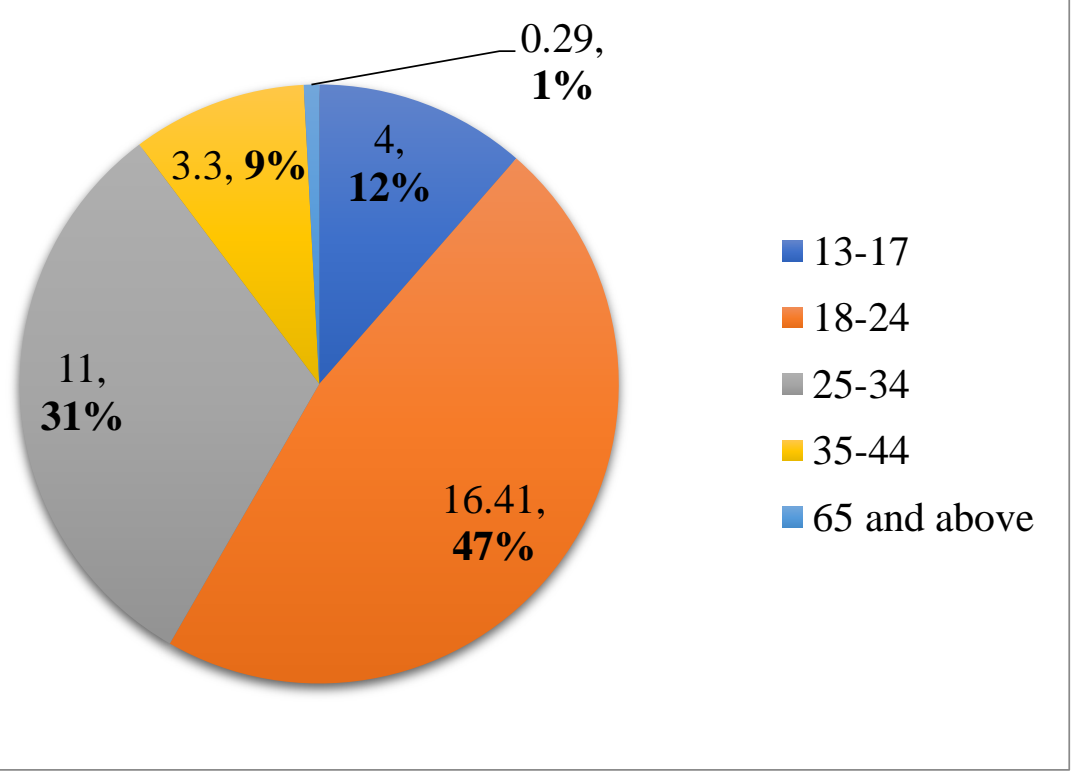

Out of total Facebook users in Pakistan, $47 \%$ belongs to the age group 18-24. The age group 25-34 stands at second with $31 \%$. After that tendency of Facebook usage is drastically decreasing with increase in the age. Only $0.85 \%$ of the age group 65 and above uses Facebook. Therefore, Facebook is most popular in the age group 18-24.

As it is clear from above statistics that social media is more popular among youngsters as compare to old aged ones in Pakistan. Excessive social media usage by Pakistani youth has a substantial influence on their relations with family members. Regardless of the fact that the trend of social media usage is at the growth stage in Pakistan, it is adversely affecting the relations of youth with their families. Social media introduction is responsible for the state of 'live together separately' in our society. Social media usage is resulting in isolation among the youth and this isolation is causing depression. The concept of individualization of family is becoming prominent day by day. Youth choose to spend their time on social media rather than with family. This situation has weakened the family bonding which was the distinctive element of our culture. 
Using social sites for enjoyment has an adverse influence on students' health. Those students who play online games and/ or who are addict to any social media site have become physically and mentally ill, different types of warning signs have been noticed among them like anxiety, fatigue, sleeplessness, frustration, and pain in the backbone. Too much usage of social media sites or playing online games for a long period also affects mental health adversely. In spite of its rising usage, massive number of users is uninformed about terms and conditions of social media. While downloading applications on their phones students often do not properly read the terms and conditions and just blindly agreed with them. Understanding the terms and conditions of any social media site is extremely crucial. It can affect the security and privacy negatively; therefore, it must be taught appropriately through different settings like awareness sessions or as a proper subject. It is necessary to spread awareness about different facets of social media (Khalid, 2017).

Education is the essential part of everyone's life, in case of youth its significance rises even more. Social media has the potential to grab the attention of students and divert them to useless chitchat; haphazard internet searching without having particular useful purposes and so on. Social media addicts have so many cybernetic friends but their excessive involvement in that is making them far from their family members, teachers, and outdoor games, which is, indeed, an alarming state. They choose to live in fantasies created by social media in their imaginations. They face problems in facing practicalities of everyday life. Understanding the other users by spying their profiles, activities, likes and dislikes, comments/ remarks etc. is quite common these days especially among the students and youngsters. This phenomenon appeals opposite genders towards each other and results in wastage of valuable time (Waqas Tariq, 2012). The other aspect of social media usage relating to education is quite bright. Using Facebook, fellow students create a group and share the lessons, presentations, projects on that group. Throughout examinations, they share important queries etc. It benefits the entire class to identify and to resolve the matters or issues in detail (Khalid, 2017).

\section{Economic Perspective of Social Media in Pakistan}

Advancement in technology affects all the spheres of human lives. Similarly, improvement in technology also greatly influences and alters the way of doing business. Companies which consider the significance of changing technological scenario and adapt their strategies accordingly remain competitive in the market, however, those firms which recognize the trend somehow late, pay the massive cost of it. Example of Nokia's (a Finnish multinational telecommunications, information technology, and consumer electronics company) decline is one of the most frequently quoted examples in this regard, the company's mobile phones were considered as the most successful brand in 90s, however due to its hesitancy in adapting the latest technology, the company is no longer a considerable player in the industry. Another example can be seen in retail industry these days. Due to the presence of online shopping platforms and increasing inclination of customers towards online purchasing, traditional retailers are facing the same challenge as they are reluctant to consider the click and mortar setting to remain competitive. Revolution of social media has significantly altered the communication patterns throughout the world. Due to ever increasing virtual availability of the target market on different social media platforms, marketing communication is observing an entirely different scenario at the moment. In last few years, Pakistan has witnessed an extensive growth in social media usage; Facebook is appearing as the most widely used social media platform by 
Pakistanis. Habitual presence of customers on different social media platforms, especially on Facebook, has attracted companies from various industries towards it. Companies in Pakistan are progressively considering the importance of social media and utilizing it as a major part of their marketing strategies (Areeba Toor, 2017).

Marketers have used several means to maintain the brand loyalty of their consumers; social media marketing is one of the modern means. Social media marketing is dissimilar than traditional ways of marketing; thus, it needs especial consideration and plan building to achieve brand loyalty. Social media marketing is linked to relationship marketing, where the companies must move from 'trying to sell' to 'association building' with the customers. The customers of today is busy and influential, thus, companies are supposed to make their presence possible on different social media sites like Facebook, Twitter, YouTube and so on. Businesses employ social media specialists and professionals to decide on content and features of their offers and activities in social media settings so that the emotions and attentions of the customers are captured (Çiçek, 2012).

Customers increasingly use social media for a range of consumption-related activities such as complaining about a product or sharing consumption experiences. On one hand, social media is offering a great opportunity for businesses to promote their brands and stay in close contact with the customers etc., but on the other hand, marketers have to deal with the current issues of this field to remain competitive in the rapidly evolving business situation (C.F. Hofacker, 2016).

Like other countries, the main source of information for people of Pakistan is social media. Almost all brands market their products through social media to reach a great number of consumers. Over the last few years, there has been a drastic change in the number of people using social media platforms; this is expected to rise in the years ahead.

Let's have a look at the prevalent marketing developments in Pakistan.

Promotion Through Videos: In the past, businesses used to promote their goods on YouTube, Vimeo, and Daily Motion. Nevertheless, this has transformed now and large companies have shifted to ads on Facebook. There are several social media marketers in Pakistan who have employed various marketing methods such as video marketing. They typically use platforms like Instagram, Snapchat, and Twitter which have thousands of users throughout the country.

Paid Marketing: Those of you who are in some way or the other related to the social media marketing industry are aware of the fact that almost all companies are fan ambitious. Businesses are in a competition to get more and more likes on their Facebook pages, and followers on Twitter. This behavior of businesses makes it apparent that in the years to come, there will be an increased trend of advertising and paid marketing through social media. Twitter is going through this stage. In recent times, 'KHAAS MIXED CHAl' by Nestle Every day was made to trend on Twitter according to a targeted budget, which is likely to be increased in upcoming days.

Buying Through Social Media: The purchasing patterns of people have changed over the past few years. Facebook has introduced the choice to purchase goods through business pages. Likewise, several other social media platforms will provide this opportunity to their users in the near future. The 'BUY' button is used fairly often by consumers to buying products, as it makes their life stressfree. According to sources, Facebook might also introduce a 'SELL' option for persons who are 
enthusiastic to sell their goods. If this occurs, purchasing and selling will both become more convenient than always.

Growing Trend of Twitter: Over the last couple of years, there has been a major rise in the activity of promotion on Twitter. Many brands try to involve Twitter users all over Pakistan. Every time you read a post on Twitter, you will notice the growing trend of hashtags used by businesses to market their goods. It can be speculated that in the future, more and more businesses will follow this strategy to make their product stand out.

Businesses in Pakistan enjoy great advantages when they begin promotion of their goods and services via social media.

Brand Awareness in Pakistan: Social media plays a notable part in increasing brand awareness. For instance, Furor, an apparel brand in Pakistan, resorted to social media to spread its name and increase its buyer base. Being totally new to the industry, the business had a lot of competitors to overcome. It overcame the rivalry by reaching out to the most renowned and followed Vloggers in Pakistan and in no time, the brand gained superiority over most of the opponents.

Website Traffic in Pakistan: The content, generally images, audio, and videos that are shared by companies on social media, appeals their target addressees to the site, increasing website traffic. This means that social media not only rises brand awareness, but also covers the method for more opportunities. Once people are taken to a company's site via a social media platform, the company experiences improved sales as well as a better ranking on search engines.

Brand Loyalty in Pakistan: Social media is the inexpensive and the most proficient method to connect with a great number of persons. This is the platform where individuals talk over your brand. There were eras when individuals used to purchase goods based on word-of-mouth brand promotion, nevertheless, those days are long vanished as societies currently go through the buyer reviews before buying.

A latest study displays that almost $\mathbf{3 5 \%}$ of consumers make choices about buying products after referring to the virtual reviews. Therefore, it is vital for businesses to create a firm reputation to raise brand loyalty. Furthermore, the quality of your product can be determined by the communications your consumers pass through social media. Being in control of this will unquestionably benefit you make an optimistic image of your brand.

Incredible Customer Approaches: Businesses marketing their brand via social media also enjoy an tremendous source of consumer insights. There is no platform better than social media to learn about the behavior of your target audience. The finest way for a business to excel is to pay attention to the inquiries and difficulties of customers and then make improvements to suit the customers' requirements.

Targeted Ads: Companies can get profitable outcomes by generating targeted ads. You can reach out to your audience based on their interests, behaviors, and other related information. You can directly reach out to those customers who you think are interested in and are eager to purchase your product.

Solutions to Customer Problems: Unlike most marketing channels, social media is a two-way source of communication. What this means is that it is not merely the company that gets to express; 
consumers also get to have their say. This permits you to get immediate response from your current and prospective consumers, permitting you to shape your product or promotions to meet their needs and wants (Shaikh, 2017).

\section{Political Perspective of Social Media in Pakistan}

There was the time when audience used to be reliant on print media and radio or television in order to obtain news regarding different national and international matters. The situation is now changed; advancement and efficiency in communication patterns have made it remarkably easy for the people of entire world to connect with one another. In order to keep an eye on current happenings, whether at national or international level, people these days rely on social media sites like Facebook, YouTube etc. Almost all news channels in Pakistan have their presence on social media sites. Social media is undoubtedly replacing print media as well as radio and television (Zafar Ali, 2013).

Social media, being youth centered platform, is attracting political parties towards it. Pakistani politicians are increasingly using social media sites in order to stay in close contact with their followers and to win the confidence of them. Different political parties utilized social media as a crucial part of their election campaign 2018.

Table-1: Results of Election 2018 - Pakistan (NA)

\begin{tabular}{|c|c|}
\hline Party & NA \\
\hline PTI & 116 \\
\hline PML-N & 64 \\
\hline PPPP & 43 \\
\hline MMA & 12 \\
\hline MQM-P & 6 \\
\hline
\end{tabular}

Table-2: Official Facebook Page Likes of Top Ranking Political Parties in Pakistan in terms of National Assembly Seats

\begin{tabular}{|cc|}
\hline Party & Official Facebook Page Likes \\
\hline PTI & $6.1 \mathrm{M}$ \\
\hline PML-N & $2.8 \mathrm{M}$ \\
\hline PPPP & $246 \mathrm{~K}$ \\
\hline MMA & $14 \mathrm{~K}$ \\
\hline MQM-P & $55 \mathrm{~K}$ \\
\hline
\end{tabular}

Source: Facebook

Pakistan Tehreek-e-Insaf (PTI) is the trend setter of social media usage in Pakistani politics; PTI focuses on youth and social media statistics make it clear that this platform is youth dominated. After PTI other political parties also started the practice of social media to achieve their political goals and 
objectives. It is quite clear from table-1 and table-2 that top 5 political parties in terms of national assembly seats have likes on their official Facebook pages accordingly; the case of MMA and MQM$P$ is excluded in this regard. In election 2013, MQM-P was the fourth largest political party with 19 national assembly seats; currently it is at no. 4 in terms of official Facebook page likes. MQM-P has its seats mostly in Karachi which is the commercial hub of Pakistan, while MMA has its seats majorly in KPK and Baluchistan, this could be one of the key reasons behind the more number of Facebook page likes of MQM-P comparatively. Another reason which should be considered as the significant one is the leadership related issues faced by the party before the election.

PTI is leading with 116 national assembly seats and 6.1M official Facebook page likes. PML-N stands at second position with 64 seats in national assembly and $2.8 \mathrm{M}$ official Facebook page likes. PPPP is the third largest political party in Pakistan with 244K official Facebook page likes and 43 national assembly seats. MMA is the fourth largest political party with 12 national assembly seats while in terms of official Facebook page likes the party stands at the fifth position with 14k likes. MQM-P is the fourth largest political party in terms of official Facebook pages while it is at no. 5 with 6 national assembly seats.

Now, it can be said that social media utilization is affecting the performance of political parties in one way or another as ranking of political parties in terms of official Facebook page likes and national assembly seats are almost the same which highlights the significance of social media in Pakistani politics.

\section{Conclusion}

The footprints of social media can be seen everywhere. In this particular study, it is tried to sum-up the impact of social media in three broad domains i.e. social, economic and political in the scenario of Pakistan. Internet users in Pakistan are increasing at a very rapid rate. Social media in Pakistan is youth and male dominated. Facebook is the most widely used social media site in the country. It is used by $92.06 \%$ of the population which has access to internet. The impact of social media largely depends on usage, on one hand, excessive usage of social media sites by youth is weakening the family bonding and relationship but on the other hand students of different grades are utilizing it as a platform where they connect with one another to share knowledge and to solve queries related to their studies. Excessive internet and social media usage is also responsible for different psychological as well as physiological diseases like anxiety, fatigue, sleeplessness, frustration, and pain in the backbone. So, it is actually the use of social media which makes it either productive or destructive. Social media marketing is different than customary methods of marketing; therefore, it requires especial attention and strategy building to attain brand loyalty. Social media marketing is associated with relationship marketing, where the businesses need to move from 'trying to sell' to 'relationship building' with the consumers. Rising demand of social media experts in different industries reveals that it is getting more and more importance in the eyes of marketers. Social media, being two-way communication channel, helping out businesses to do one-on-one marketing. It is the most reliable source of customers' feedback which is undoubtedly the basis of improvement for different organizations.

As social media is youth dominated platform, therefore, it is attracting political parties towards it. Pakistani politicians are using social media sites in order to stay in close contact with their supporters 
and to win the confidence of them. Different political parties used social media as a vital part of their election promotion 2018. Social media usage has an influence on the the performance of political parties. The position of political parties in terms of official Facebook page likes and national assembly seats are nearly the same which highlights the importance of social media in Pakistani political affairs. So, in conclusion we can say that the effects of social media are not confined to any particular area rather it can be seen in all the dimensions i.e. social, economic and political. This situation reveals that the knowledge and familiarity of social media is a must for every member of our society as it is simultaneously destructive and constructive depending on how ones utilize it.

\section{Contribution to Existing Knowledge}

Social media is one the most influential electronic tool in the current era. The importance of this tool has been discussed in detail i.e. how it affects the entire political environment of Pakistan. Additionally, how this tool has been providing awareness to the public about the credibility of political parties that are working in Pakistan. The leadership of these political parties is also utilizing the same platform in order to convey messages to the public and their supporters. On the other hand, army also uses this stage to communicate with the public that helps them to follow up most of the activities that happen on social media.

\section{References}

Areeba Toor, M. H. (2017). The Impact of Social Network Marketing on Consumer Purchase Intention in Pakistan: Consumer Engagement as a Mediator. Asian Journal of Business and Accounting, 10(1), 168, 169.

Hofacker, D. B. (2016). Eight social media challenges for marketing managers. SPANISH JOURNAL OF MARKETING - ESIC, 73.

Çiçek, I. E.-E. (2012). The impact of social media marketing on brand loyalty. (p. 1355). Elsevier.

Facebook. (2018). Bilawalhouse. Retrieved 8 10, 2018, from Facebook: https://www.facebook.com/Bilawalhouse/

Facebook. (2018). MMAJIPOfficial. Retrieved 8 10, 2018, from Facebook: https://www.facebook.com/MMAJIPOfficial/

Facebook. (2018). MQM.Pakistan. Retrieved 8 10, 2018, from Facebook: https://www.facebook.com/MQM.Pakistan/

Facebook. (2018). pml.n.official. Retrieved 8 10, 2018, from Facebook: https://www.facebook.com/pml.n.official/

Facebook. (2018). PTIOfficial. Retrieved 8 10, 2018, from Facebook: https://www.facebook.com/PTIOfficial/

Khalid, H. (2017). The Effects of Social Networks on Pakistani Students. Journal of Information Technology \& Software Engineering, 7(3), 5.

Noshina Saleem, Q.-t.-a. M. (2014). Influence of Social Networking Sites on Interaction Patterns of Youth: A Pakistani Case. Pakistan Vision, 15(1), 44, 45, 54, 55.

Pro, A. (2018). Pakistan Social Media Stats 2018. Retrieved from Alpha Pro: http://alphapro.pk/pakistan-social-media-stats-2018/ 
Shaikh, M. A. (2017, December 28). Social Media Marketing In Pakistan [Strategy Canvas 2018]. Retrieved from Mega Marketing Network.com : http://megamarketingnetwork.com/socialmedia-marketing-pakistan/

Stats, I. W. (2017, December). Pakistan. Retrieved from Internet World Stats: https://www.internetworldstats.com/asia/pk.htm

Today, P. b. (2018). Pakistan's social media landscape dominated by males, females lag behind: Report. Retrieved from Profit by Pakistan Today: https://profit.pakistantoday.com.pk/2018/04/18/pakistans-social-media-landscapedominated-by-males-females-lag-behind-report/

TV, G. (2018). Pakistan Election 2018: Results. Retrieved from Geo TV: https://www.geo.tv/election/results

Waqas Tariq, M. M. (2012). The Impact of Social Media and Social Networks on Education and Students of Pakistan. International Journal of Computer Science, 9(4), 409.

Zafar Ali, M. J. (2013). SOCIAL MEDIA IMPLICATION ON POLITICS OF PAKISTAN; MEASURING THE IMPACT OF FACEBOOK. The International Asian Research Journal, 1(1), 13. 